\title{
Interaction of the model alkyltrimethylammonium ions with alkali halide salts: an explicit water molecular dynamics study|*
}

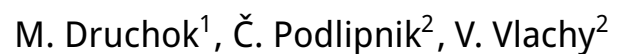 \\ ${ }^{1}$ Institute for Condensed Matter Physics, 1 Svientsitskii St., 79011 Lviv, Ukraine \\ 2 Faculty of Chemistry and Chemical Technology, University of Ljubljana, 5 Aškerčeva St., 1000 Ljubljana, Slovenia
}

Received July 24, 2013, in final form August 29, 2013

We present an explicit water molecular dynamics simulation of dilute solutions of model alkyltrimethylammonium surfactant ions (number of methylene groups in the tail is 3,5,8,10, and 12) in mixture with $\mathrm{NaF}, \mathrm{NaCl}$, $\mathrm{NaBr}$, and NaI salts, respectively. The SPC/E model is used to describe water molecules. Results of the simulation at $298 \mathrm{~K}$ are presented in the form of radial distribution functions between nitrogen and carbon atoms of $\mathrm{CH}_{2}$ groups on the alkyltrimethylammonium ion, and the counterion species in the solution. The running coordination numbers between carbon atoms of surfactants and counterions are also calculated. We show that $\mathrm{I}^{-}$counterion exhibits the highest, and $\mathrm{F}^{-}$the lowest affinity to "bind" to the model surfactants. The results are discussed in view of the available experimental and simulation data for this and similar solutions.

Key words: surfactants, alkyltrimethylammonium salts, alkali halides, ion binding, molecular dynamics

PACS: $61.20 . J a, 61.20 . Q g, 82.20 . W t, 82.30 . R s, 82.35 . R s$

\section{Introduction}

It has long been known that properties of surfactant solutions, for example critical micelle concentration, depend on the nature of the counterion present in solution [1-7]. The latter effect being of particular interest to us, it is further examined herein using the explicit water molecular dynamics method. In view of our present study, important experimental results were presented by Rožycka-Roszak et al. [3]. This group performed calorimetric measurements (see figure 1 of their paper) showing that upon dissociation of the dodecyltrimethylammonium bromide micelle, the heat is consumed. In contrast to this, the dissociation of dodecyltrimethylammonium chloride micelles is exothermic, i.e., heat is released. The experiments also indicated that the two halide ions influence the process of micelle formation in a completely different way.

The situation closely resembles the one observed in recent experimental studies of aliphatic $x, y$ ionenes [8-10]. Ionenes are cationic polyelectrolytes with a different ( $x, y$ may vary from 3,3 to 12,12 ) number of methylene groups between the quaternary ammonium groups. Notice that aliphatic ionenes are similar in chemical structure to the alkyltrimethylammonium ions studied here. For example, the monomer unit of the 12,12-ionene is actually the dodecyltrimethylammonium ion. The heats of dilution of the $x, y$-ionenes indicate a strong difference between the salts with different counterions. The results for $x, y$-ionene fluorides are exothermic and rather well follow the theoretical results based on the continuum solvent models. The salts with bromide, chloride, and iodide anions as counterions show different behavior [8, 11]: heat of dilution may be either endothermic or exothermic depending on the length of the hydrophobic portion of the charge. Moreover, the most recent experimental data indicated [12] that additions of extra methylene groups (transition from 6,12- to 12,12-ionene) affect the solutions with different counterions differently.

\footnotetext{
* It is a pleasure to dedicate this paper to our good friend and coworker Professor M.F. Holovko.
} 
Among the theoretical methods of probing the hydration in the explicit water models, the molecular dynamics simulations seem to be the most useful (see, for example, references [13-16]). In the present explicit water molecular dynamics study we are interested in the effects of an increasing number of methylene groups (i.e., the length of the surfactant tail) on the interaction between the various counterion species in a solution and quaternary ammonium group of the surfactant. For this purpose, we performed the study of mixtures of alkyltrymethylammonium surfactant ions with fluoride, chloride, bromide, and iodide counterions in mixture with $\mathrm{NaF}, \mathrm{NaCl}, \mathrm{NaBr}$, and $\mathrm{NaI}$ salts, respectively. The simulation is focused on very dilute solutions with respect to surfactant. In this way, the counterion-charged group interaction can be studied without possible complications of the polyion chain association. The study accordingly applies to the conditions well below the critical micelle concentration. The surfactant molecules with the tail, containing from three to twelve $\mathrm{CH}_{2}$ groups, are probed.

\section{Model and simulation details}

A set of surfactant solutions containing alkylammonium ions, sodium co-ions, neutralizing halide counterions, and water molecules are investigated. To obtain insights into the specific ion effects, we examined a series of halide salts: fluorides, chlorides, bromides, and iodides. The respective counterions are characterized by the same charge but different crystal size, so one can expect a somewhat different interaction of the counterion with the surfactant (quaternary ammonium) ion. The latter ion consists of the quaternary nitrogen, neighbored by three $\mathrm{CH}_{3}$-groups, a carbon chain with $\mathrm{CH}_{2}$ groups and a terminal $\mathrm{CH}_{3}$ group. As an example, in figure 1 we show the surfactant ion with five carbons in the tail. In the present study we considered surfactants with five different tail lengths; i.e., with 3-, 5-, 8-, 10-, and 12 carbons denoted as $\mathrm{C}_{3}, \mathrm{C}_{5}, \mathrm{C}_{8}, \mathrm{C}_{10}$, and $\mathrm{C}_{12}$. The wide spectrum of chain lengths allows us to study the effect of hydrophobicity on the counterion-quaternary ammonium interaction.

All the particles in the system were treated on equal footing. Water was described within the SPC/E model [17]. The Lennard-Jones parameters for $\mathrm{Na}^{+}$ions were taken from reference [18], the ones for the halide ions - from the work by Palinkas [19]. The Lennard-Jones parameters for the sites of a surfactant were taken from the OPLS force field [20]. Charges at the atoms of surfactants were fitted from the electrostatic potential calculated with DFT B3LYP/6-311G** using Jaguar 7.9 (Schrödinger Suite) [21]. Listing these charges in the form of tables for the whole atom simulation is far from optimal. As an example, figure 1 shows the distribution of charges for $\mathrm{C}_{5}$, while all interested readers are encouraged to request the full information from authors via e-mail. In order to preserve the intramolecular geometry of the surfactants, we have utilized a set of bond and angular potentials in the

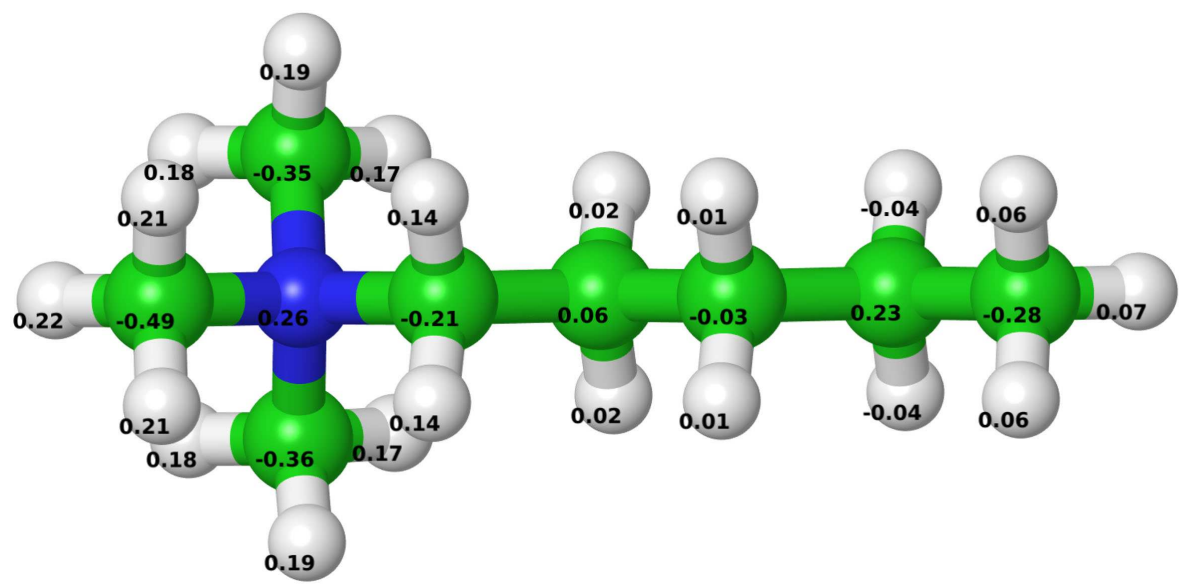

Figure 1. (Color online) Schematic representation of the alkylammonium ion with five methyl groups in the tail. Nitrogen is indicated by blue, carbons by green, and hydrogens by white color. The numbers show optimized atomic charges. 
Table 1. Model parameters.

\begin{tabular}{|c|c|c|c|}
\hline & species & $\epsilon$ (kcal/mol) & $\sigma(\AA)$ \\
\hline \hline water & $\mathrm{O}$ & 0.1554 & 3.1656 \\
& $\mathrm{H}$ & 0.0 & 0.0 \\
\hline \multirow{4}{*}{$\mathrm{AA}$} & $\mathrm{N}$ & 0.170 & 3.25 \\
& $\mathrm{C}$ & 0.066 & 3.50 \\
& $\mathrm{H}$ & 0.030 & 2.5 \\
\hline \multirow{4}{*}{ electrolyte } & $\mathrm{Na}$ & 0.0028 & 3.3304 \\
& $\mathrm{~F}$ & 0.0118 & 4.0 \\
& $\mathrm{Cl}$ & 0.0403 & 4.86 \\
& $\mathrm{Br}$ & 0.0645 & 5.04 \\
& $\mathrm{I}$ & 0.0979 & 5.40 \\
\hline
\end{tabular}

form $U=k_{\text {bond }}\left(r-r_{0}\right)^{2}$ and $U=k_{\text {angle }}\left(\alpha-\alpha_{0}\right)^{2}$. The carbon-carbon and nitrogen-carbon distances $r_{0}$ in the surfactant backbone are $1.5 \AA$ with the corresponding $k_{\text {bond }}=500 \mathrm{kcal} / \mathrm{mol} / \AA^{2}$, the parameters for the backbone angles $-\alpha_{0}=111^{\circ}, k_{\text {angle }}=250 \mathrm{kcal} / \mathrm{mol}$. The parameters for the carbon-hydrogen bonds in $\mathrm{CH}_{2}$ and $\mathrm{CH}_{3}$ groups are $250 \mathrm{kcal} / \mathrm{mol} / \AA^{2}$ and $1.1 \AA$. For the hydrogen-hydrogen distances inside $\mathrm{CH}_{2}$ and $\mathrm{CH}_{3}$ groups we used additional constraints with parameters $150 \mathrm{kcal} / \mathrm{mol} / \AA^{2}, 1.8 \AA$. As for two off-backbone $\mathrm{CH}_{3}$ groups, the corresponding carbon-nitrogen-carbon angle is controlled by the angular potential $250\left(\alpha-109^{\circ}\right) \mathrm{kcal} / \mathrm{mol}$. Finally, for the surfactant rigidity we also applied a set of angular potentials $250\left(\alpha-180^{\circ}\right) \mathrm{kcal} / \mathrm{mol}$ between next but one backbone carbons (first-third-fifth atom, secondfourth-sixth, ...).

The Lennard-Jones parameters $\left(\sigma_{i}, \epsilon_{i}\right)$ assigned to various atoms or ions are shown in table 1 For unlike sites, the parameters were obtained using the mixing rules in the form $\sigma_{i j}=\frac{1}{2}\left(\sigma_{i}+\sigma_{j}\right)$ and $\epsilon_{i j}=\sqrt{\epsilon_{i} \epsilon_{j}}$. A standard DL_POLY [22] package was used for molecular dynamics simulations of model solutions with the unit cell containing 2352 water molecules, one surfactant ion, one counterion $\mathrm{X}$ (X can be $\mathrm{F}^{-}, \mathrm{Cl}^{-}, \mathrm{Br}^{-}$, or $\mathrm{I}^{-}$), and $6 \mathrm{Na}+\mathrm{X}$ pairs modelling the added salt. The concentration $c_{s}$ of the added lowmolecular electrolyte $\mathrm{Na}^{+} \mathrm{X}^{-}$was $\approx 0.14 \mathrm{~mol} \mathrm{dm}^{-3}$. All the species were allowed to move freely across the cubic cell with periodic boundary conditions. The long-range Coulomb interactions were taken into account by the Ewald summation technique. The short-range interactions ware truncated at $R_{\text {cut }}=15 \AA$. The pressure ( 1 bar) and temperature $(298 \mathrm{~K})$ were controlled by means of a Nose-Hoover barostat and thermostat in an isotropic $N, P, T$ ensemble within the Melchiona modification [23]. The number of steps in the production runs ranged from 3.5 to $4.0 \times 10^{7}$ with the time step $5 \times 10^{-16} \mathrm{~s}$. Such a time step is needed to satisfy the constraints imposed by the bond and angular intramolecular potentials for water and surfactants. The radial distribution functions (RDF) between various sites on the molecule and ions in solution are presented in the form of graphs.

\section{Numerical results}

\subsection{Radial distribution functions}

First, in figure 2 we consider the nitrogen-counterion radial distribution functions. Notice that in all the solutions studied here an extra sodium salt ( $\mathrm{NaX}, \mathrm{X}^{-}$is the counterion) is present. The plots show that fluoride counterions tend to be located in the bulk of the solution (away from the surfactant ion), demonstrating poor correlation with the quaternary ammonium ion. This behavior is a consequence of strong hydration of fluoride ion, preventing "association" of fluoride ions with the nitrogen group on the surfactant, as we already know from the experimental [8-10] and theoretical [24, 25] studies of $x, y$ ionene solutions. The halides of larger sizes, such as chloride, bromide, and iodide counterions, are less strongly hydrated (their free energies of hydration are smaller in magnitude than that of fluoride ion) and can, therefore, release some water molecules in interaction with the quaternary nitrogen group on 

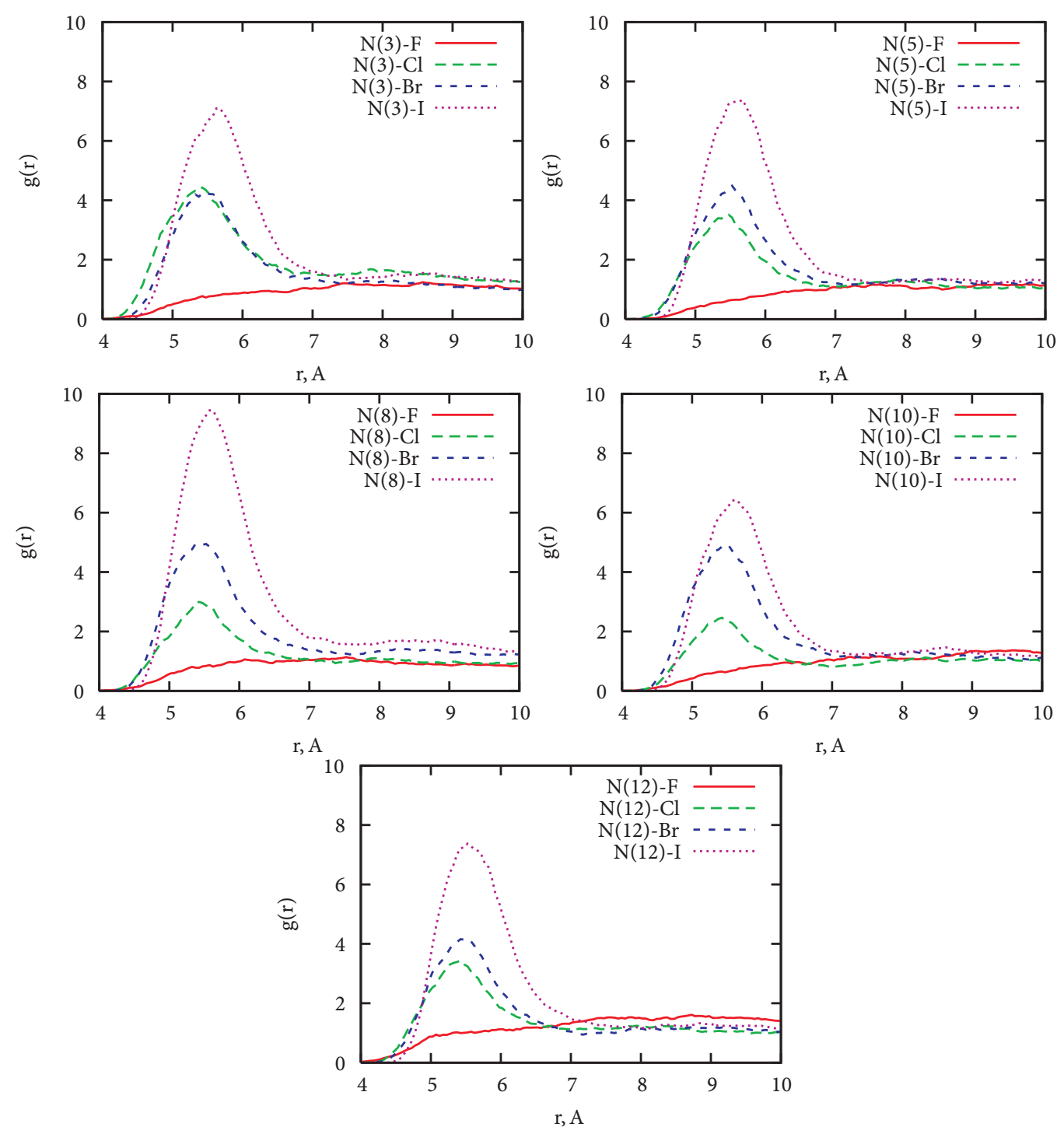

Figure 2. (Color online) Nitrogen-counterion RDFs for molecule with (a) three methylene groups, $\mathrm{C}_{3}$, (b) $\mathrm{C}_{5}$, (c) $\mathrm{C}_{8}$, (d) $\mathrm{C}_{10}$, and (e) $\mathrm{C}_{12}$. The results for fluorides are denoted by full red lines, for chlorides by dashed green lines, bromides are denoted by short-dashed blue, and iodides by dotted magenta lines.

the surfactant. This causes the nitrogen-counterion peak height to follow the ordering: $\mathrm{I}^{-}>\mathrm{Br}^{-}>\mathrm{Cl}^{-}>$ $\mathrm{F}^{-}$. This is valid for all the surfactants studied here, an exception being the shortest one, $\mathrm{C}_{3}$, where the peak heights of the chloride and bromide ions are approximately the same.

Different halide ions follow different sequences of the first peak height with respect to the chain length: for strongly solvated chlorides, the shortest, $\mathrm{C}_{3}$, surfactant has the highest peak. The peak height then decreases in the order $\mathrm{C}_{3}>\mathrm{C}_{5}>\mathrm{C}_{12}>\mathrm{C}_{8}>\mathrm{C}_{10}$. In contrast with chlorides, the iodide salts, which are known to release their hydration waters more easily, reveal a different dependence of the magnitude of the first RDF peak. The highest value is obtained for $\mathrm{C}_{8}: \mathrm{C}_{8}>\mathrm{C}_{5} \approx \mathrm{C}_{12}>\mathrm{C}_{3}>\mathrm{C}_{10}$. Here, the number of methylene groups becomes more important; a higher number of $\mathrm{CH}_{2}$ groups means a stronger attraction. The balance between the Coulomb (charge density decreases with the chain length) and van der Waals attraction, which increases with the number of methylene groups in the chain, produces the observed sequence. Notice that, according to literature, the iodide ion is considered to have more affinity for hydrophobic surfaces than other halide ions [26]. The peak sequence for bromides reveals the lowest value for $\mathrm{C}_{12}$, the others run close with a slight prevalence of the $\mathrm{C}_{8}$ one, like it is found for the iodide solutions. 

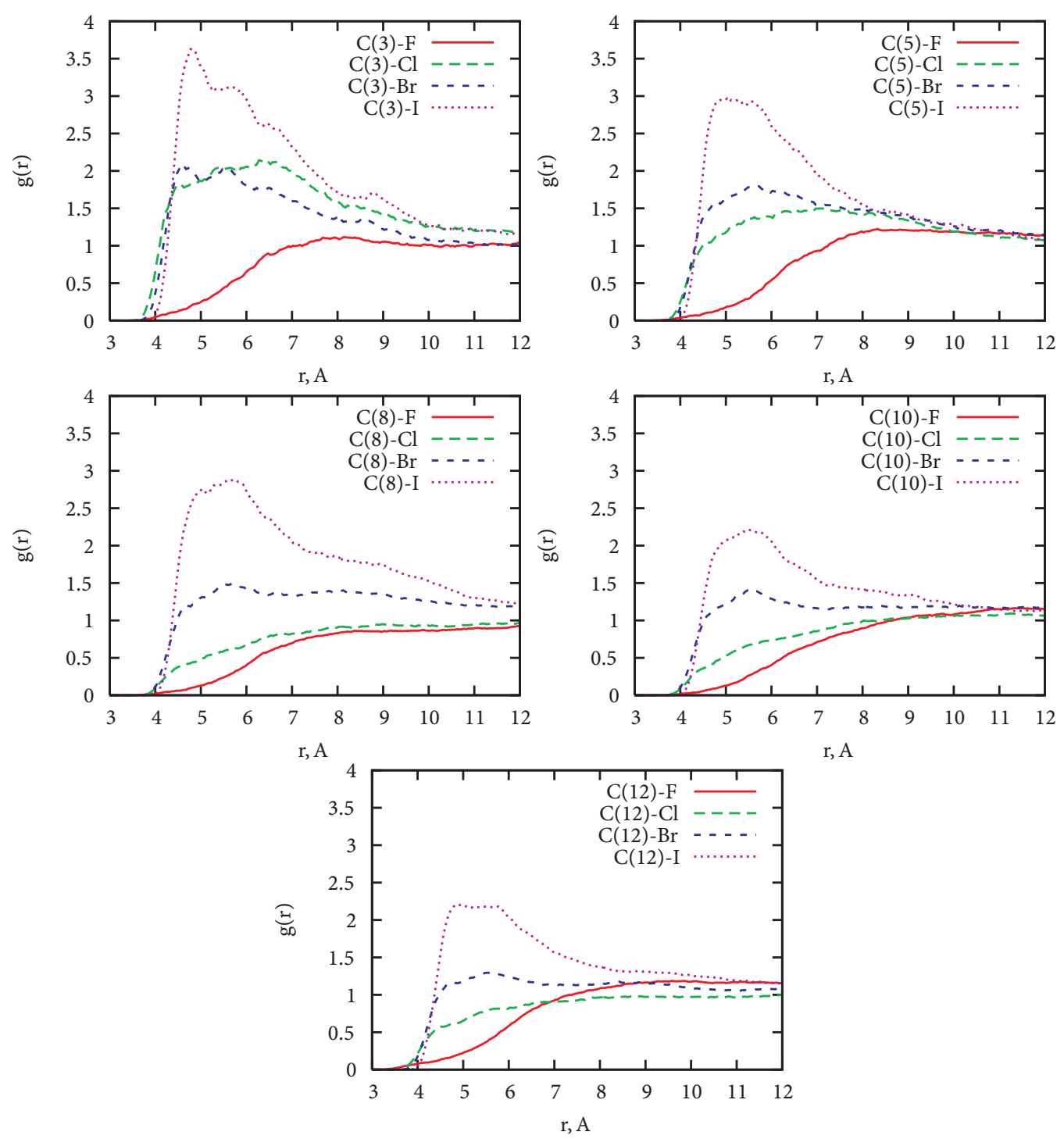

Figure 3. (Color online) Carbon-counterion radial distribution functions. The legend as for figure 2

These results are complemented by the carbon-counterion radial distribution functions (figure 3). Notice that only the carbons from the surfactant tails are included into this RDF calculation; the contribution of carbons of $\mathrm{CH}_{3}$ groups neighboring to nitrogens is neglected. The sequence of carbon-counterion peak heights is: $\mathrm{I}^{-}>\mathrm{Br}^{-}>\mathrm{Cl}^{-}>\mathrm{F}^{-}$. Again an exception is the shortest molecule $\left(\mathrm{C}_{3}\right)$, where the peak heights of the chloride and bromide counterions are approximately the same. Peaks of these distribution functions are generally lower than those of the counterion-nitrogen distributions, indicating a weaker accumulation of counterions next to the surfactant tail. Similar to the nitrogen-fluoride radial distribution functions, the carbon-fluoride ones exhibit merely a weak correlation, confirming the conclusion about marginal "association" of $\mathrm{F}^{-}$ions with the surfactant molecules. The carbon-chloride distribution functions demonstrate a quite expected sequence of the RDF peak heights: the highest is $\mathrm{C}_{3}$ peak, next goes $\mathrm{C}_{5}$, then $\mathrm{C}_{8} \approx \mathrm{C}_{10} \approx \mathrm{C}_{12}$. This indicates that the relatively strongly solvated chloride counterions exhibit little (or no) affinity for surfactants with longer tails. The carbon-iodide pair distribution functions demonstrate a higher peak for $\mathrm{C}_{3}$ than $\mathrm{C}_{5} \approx \mathrm{C}_{8}$, while the lowest are the peaks for $\mathrm{C}_{10}$ and $\mathrm{C}_{12}$. The counterion-carbon interaction, as judged on the basis of these RDFs, is stronger for $\mathrm{I}^{-}$than for $\mathrm{Cl}^{-}$, and this effect is quite prominent for longer surfactants [26]. 


\subsection{Running coordination numbers}

Each of the surfactant species carries one charged group but a different number of methylene groups $\left(C_{x}\right)$, which obscures the direct comparison (nitrogen-counterion vs carbon-counterion) of the RDFs discussed above. For this reason, we also present the so-called running coordination numbers as an alternative way of data analysis. This quantity, $n_{\alpha \beta}(r)$, is defined as a number of particles $\beta$ in a sphere of radius $r$ around a certain particle $\alpha$ in the center:

$$
n_{\alpha \beta}(r)=4 \pi \rho_{\beta} \int_{0}^{r} g_{\alpha \beta}\left(r^{\prime}\right) r^{\prime 2} \mathrm{~d} r^{\prime},
$$

where $\rho_{\beta}$ is a number density of species $\beta$ in the system. We denote the counterion species with subscript $\alpha$ and carbon of the methylene group with $\beta$, so the coordination numbers reflect the probability to find a carbon atom in the sphere around a counterion (figure 4). This permits a more realistic presentation of the counterion accumulation around the methylene groups, as it can be inferred from the relevant pair distribution functions alone. The conclusion emerging from figure 4 is that fluoride ions are the least, and iodide counterions the most strongly coordinated to carbon atoms, while the other counterions fit in-between. Generally, the running coordination numbers for $\mathrm{C}_{12}$ are the highest, with a decrease in the direction toward $C_{3}$. The present observation reflects the fact that $C_{12}$ solutions contain more carbons than the $\mathrm{C}_{3}$ ones. The running coordination numbers for fluorides demonstrate a monotonous dependence on the length of the hydrophobic chain.

For less hydrated chlorides, the picture complicates: the $\mathrm{C}_{8}$ running coordination number (for a region of distances up to $8 \AA$ ) runs bellow the other corresponding functions. One should also note a relatively small difference between $\mathrm{C}_{12}$ and $\mathrm{C}_{3}$ running coordination numbers for the fluoride and chloride solutions. This finding is consistent with the suggestion drawn on the basis of the nitrogen-fluoride/chloride
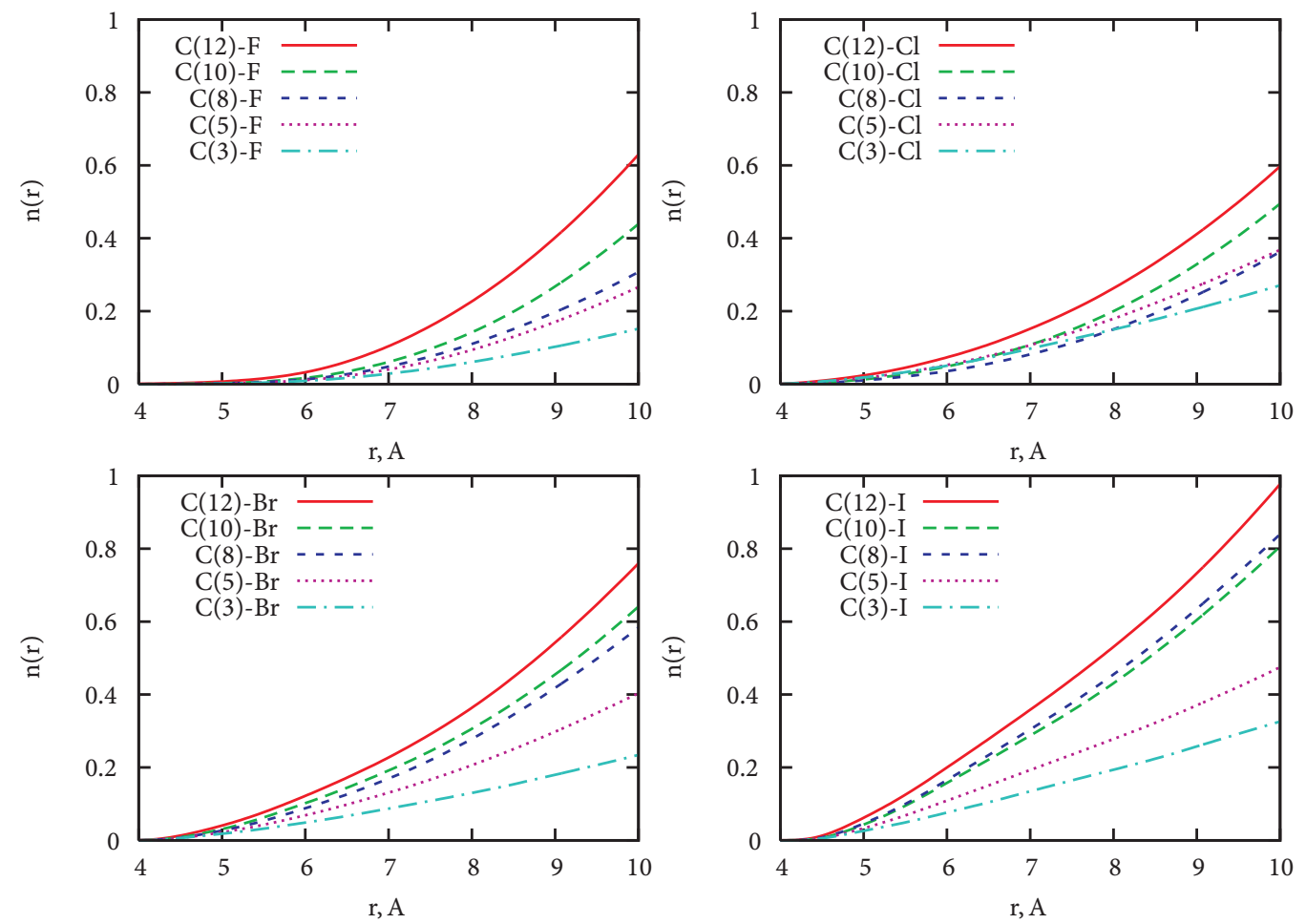

Figure 4. (Color online) Counterion-carbon running coordination numbers for the fluorides (top left), chlorides (right), bromides (bottom left), and iodides (right hand panel). $\mathrm{C}_{12}$ results are denoted by full red lines, $C_{10}-$ dashed green, $C_{8}-$ short-dashed blue, $C_{5}-$ dotted magenta, and $C_{3}$ results are denoted by dash-dotted cyan lines. 

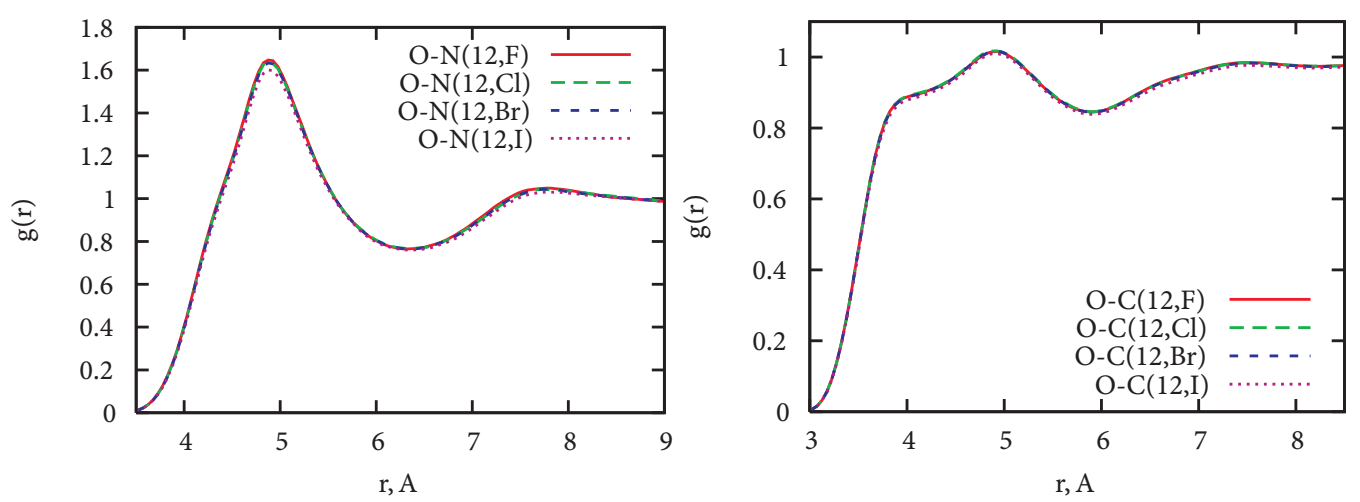

Figure 5. (Color online) Oxygen-nitrogen (left-hand) and oxygen-carbon (right-hand) RDFs for molecule with twelve methylene groups, $\mathrm{C}_{12}$. The results for fluorides are denoted by full red lines, for chlorides by dashed green lines, bromides are denoted by short-dashed blue, and iodides by dotted magenta lines.

RDFs: the origin of the attraction between surfactants and counterions is mainly of electrostatic nature. The picture changes if one considers bromide and iodide solutions. The gap between $C_{12}$ and $C_{3}$ values becomes more significant, moreover, for the iodide case, the $\mathrm{C}_{8}$ running coordination numbers exceed $\mathrm{C}_{10}$ values. This agrees with the jump seen above in the $\mathrm{C}_{8}$-iodide RDFs (figure 2). We ascribe this behavior to the competition between Coulomb and van der Waals interactions; while the importance of the former decreases with an increasing chain length, just an opposite is true for the van der Waals forces. We have also calculated the counterion-nitrogen running coordination numbers. These data seem to merely confirm the insights obtained from the radial distribution functions presented in figure 2 and are, therefore, not shown here.

\subsection{Hydration of the quaternary ammonium and methylene groups}

To document the effect of the counterion species on the hydration of the surfactant we collected the oxygen-nitrogen and oxygen-carbon (methylene group) radial distribution functions. All the surfactans studied here exhibit the same trends as far as the counterion species is concerned, so only the data for the longest one, $\mathrm{C}_{12}$, are presented in more detail (see figure 5). Oxygen-nitrogen radial distribution functions: the position of the first peak remains unchanged, but its height slightly decreases along the sequence $\mathrm{F} / \mathrm{Cl} / \mathrm{Br} / \mathrm{I}$. This result indicates that large and loosely hydrated counterions win against waters in competition for the vacancies near surfactant ions. A similar effect has been earlier observed in the studies of 3,3- and 6,6-ionene oligomers in water [24, 25].

The right hand panel of figure 5 presents the oxygen-carbon radial distribution functions. The differences between the radial distribution functions belonging to different counterions are even smaller here. It is the iodide radial distribution function which has the smallest peak, confirming the observation mentioned above. Finally, the shapes of the oxygen-nitrogen and oxygen-carbon (methylene group) radial distribution functions are the same as observed before for $x, y$-ionene oligomers in water [24, 25]. Much weaker hydration (drying) of the methylene groups in comparison with the positively charged nitrogen group is clearly visible.

We expect for the positively charged surfactant head to orient neighboring water molecules in such a way that an oxygen points toward, and hydrogens away from the head. In addition, we are interested in the orientation of water molecules near the hydrophobic tail. A water molecule is considered to be a part of the surfactant hydration shell if the distance between oxygen and nitrogen is less than $6.3 \AA$, or the distance between the oxygen and tail carbon is less than $4.3 \AA$. Notice that the carbons attached directly to nitrogen are not included in the statistics. These distances are the positions of the corresponding first minima of the nitrogen-oxygen and carbon-oxygen RDFs (figure 5). We monitored the angle between the dipole moment of a (hydrating) water molecule and a vector pointing from oxygen to the nearest carbon or nitrogen. Following this definition, we accumulated two types of angular distribution functions. The first one describes orientations of hydrating waters in the vicinity of nitrogen (charged head), and the 
second one near the carbons of hydrophobic tail. To illustrate the difference, we discuss these data in terms of average angles. It is interesting that the angles averaged over the waters near the "nitrogen" group show little dependence on the counterion type, or on the length of the hydrophobic tail. The variation of this angle is in the range between 97 to $100^{\circ}$. Contrary to this, the orientation distribution of the waters near "carbons" demonstrates a spread from $91^{\circ}$ for $C_{12}$ to $97^{\circ}$ for $C_{3}$. The result reflects the fact that for shorter surfactants with higher charge density, hydrating waters are more affected than for the longer $\left(\mathrm{C}_{12}\right)$ ones.

\section{Discussion}

The quaternary ammonium group is a part of many important molecules. One such example are aliphatic $x, y$-ionenes, where $x$ and $y$ denote the numbers of methylene groups between the two adjacent quaternary nitrogens. These cationic polyelectrolytes can be synthesized with different charge density, varying $x, y$ numbers from 3 to 12 (see, for example [27-30]). Recently in a series of papers we had studied aqueous solutions of $x, y$-ionenes using different experimental methods [8-10]. In addition, the molecular dynamics simulations of the 3,3- and 6,6-ionenes were performed [24, 25].

The repeating monomer unit of the 3,3-ionene polyelectrolyte is composed of the quaternary ammonium group followed by three methylene groups. Similarly, the repeating unit of 12,12-ionene is the quaternary ammonium group followed by twelve $\mathrm{CH}_{2}$ groups. It is quite clear from this that our model $\mathrm{C}_{12}$ surfactant can be "identified" as a monomer unit (with an exception of the terminal hydrogen) of the 12,12-ionene polycation. With the same logic, the model $C_{3}$ surfactant is a building block of the 3,3ionene, while the $C_{5}$ and $C_{8}$ roughly correspond to the 6,6-ionene. This makes it worthwhile to compare the present simulations with those for 3,3- and 6,6-ionene oligoions in explicit water. Unfortunately, no molecular dynamic simulations for the 12,12-ionene solutions exist so far.

Here, we compare the pair distribution functions shown in figures 2 and 3 with those published in references [24] (see figures 4 and 5 of that paper), and [25] (figure 3). Considering that the force field used in both calculations is very similar, more or less similar results are expected. The eventually observed differences between the two results could only be attributed to an accumulation of the charge on the oligoion with six monomer units. The heights of the peaks in figure 4 (see reference [24]) follow the trend $\mathrm{NaF}<\mathrm{NaCl}<\mathrm{NaBr}<\mathrm{NaI}$. The same holds true for the carbon-counterion RDFs shown in figure 5 of the same paper, except that now the iodide and bromide peaks are very close to each other. In other words, the trends exhibited by "monomers" are also reproduced by short oligoions in water. Useful information on the specific ion effects in polyelectrolyte solutions may often be obtained by studying monomer systems, as it was demonstrated for salts of para-toluene(sulphonic) acid [31], and for tetraalkylammonium halides in water (see reference [32], and the references therein). A word of caution is needed with respect to this statement. Recent measurements by Čebašek and coworkers [12] show that for sufficiently hydrophobic 12,12-ionenes, the trends with respect to the nature of counterion (Hofmeister series) may be reversed in comparison with the more charged (less hydrophobic) 3,3-ionenes.

The experimental results for the alkyltrimethylammonium surfactant solutions, which partially include the pre-micellar region, have been presented by several authors [1, 2, 5, 7]. Since the critical micelle concentrations for surfactants with long chains $\left(\mathrm{C}_{12}\right.$ and more) are very low, the data are not collected systematically. Among these studies it is worth mentioning the work by Jakubowska [7] who used mass spectrometry to investigate the affinity of counterions to surfactant monomers in the gas phase. She examined the sodium hexadecyl-N,N,N-trimethyl ammonium bromide in the presence of various salts. The results suggested the following ordering in the affinity of counterions for this surfactant: $\mathrm{F}^{-}<\mathrm{Cl}^{-}<\mathrm{NO}_{3}^{-}$.

Enthalpies of dilution of various surfactants have been measured in pre-micellar region by Birch and Hall [1]; see figure 1 of their paper. The authors compare their results with the results by the DebyeHückel limiting law. Surfactant ions (alkyltrimethyl ammonium bromides, $\mathrm{C}_{n} \mathrm{TAB}$ ) with a number of carbon atoms $n$ from 6 to 12 were examined. The surfactants exhibit both positive and negative deviations from the limiting law. The ordering of the surfactants, from negative to positive deviations is: $\mathrm{C}_{6} \mathrm{TAB}<\mathrm{C}_{8} \mathrm{TAB}<\mathrm{C}_{10} \mathrm{TAB}<\mathrm{C}_{12} \mathrm{TAB}$. This finding appears to be in qualitative agreement with the results for counterion-carbon coordination number presented in figure 4. 


\section{Conclusions}

The explicit water molecular dynamics simulations of dilute solutions of model alkyltrimethylammonium surfactant ions (the number of carbon atoms in the tail is 3, 5, 8, 10, and 12) in mixture with NaF, $\mathrm{NaCl}, \mathrm{NaBr}$, and NaI, are performed. The results are presented in the form of relevant radial distribution functions; in addition, the running coordination numbers for the counterion-carbon distributions are evaluated. The nitrogen-counterion correlations seem to primarily depend on the Coulomb interaction. On the other hand, the carbon-counterion distribution coordination numbers seem to be also affected by the van der Waals forces. The molecular dynamics results presented here are consistent with the experimental data for alkyltrimethyl ammonium salts taken in the pre-micellar region. Furthermore, the results agree with similar simulations performed for aliphatic $x, y$-ionene solutions, and with experimental findings for the surfactant and polyelectrolyte systems containing a quaternary ammonium group.

\section{Acknowledgements}

This study was supported by the Slovenian Research Agency fund (ARRS) through the Program 01030201, and Project J1-4148.

\section{References}

1. Birch B.J., Hall D.G., J. Chem. Soc., Faraday Trans. 1, 1972, 68, 2350; doi 10.1039/F19726802350

2. De Lisi R., Fisicaro E., Milioto S., J. Solution Chem., 1988, 17, 1015; doi 10.1007/BF00647799

3. Rožycka-Roszak B., Zylka R., Kral T., Przyczyna A., Z. Naturforsch. C, 2001, 56, 407.

4. Perger T.M., Bešter-Rogač M., J. Coll. Interface Sci., 2007, 313, 288; doi 10.1016/j.jcis.2007.04.043

5. Jakubowska A., Chem. Phys. Chem., 2008, 9, 829; doi 10.1002/cphc.200700763

6. Šarac B., Bešter-Rogač M., J. Coll. Interface Sci., 2009, 338, 216; doi 10.1016/j.jcis.2009.06.027

7. Jakubowska A., J. Coll. Interface Sci., 2010, 346, 398; doi 10.1016/j.jcis.2010.03.043

8. Čebašek S., Lukšič M., Pohar C., Vlachy V., J. Chem. Eng. Data, 2011, 56, 1282; doi 10.1021/je101136a.

9. Bončina M., Lukšič M., Druchok M., Vlachy V., Phys. Chem. Chem. Phys., 2012, 14, 2024; doi 10.1039/c2cp23137a

10. Seručnik M., Bončina M., Lukšič M., Vlachy V., Phys. Chem. Chem. Phys., 2012, 14, 6805; doi 10.1039/C2CP40571G

11. Arh K., Pohar C., Acta Chim. Slov., 2001, 48, 385.

12. Čebašek S., Seručnik M., Vlachy V., J. Phys. Chem. B, 2013, 117, 3682; doi 10.1021/jp401313f

13. Lounnas V., Lüdemann S.K., Wade R.C., Biophys. Chem., 1999, 78, 157; doi 10.1016/S0301-4622(98)00237-3

14. Patsahan T., Holovko M., Condens. Matter Phys., 2007, 10, 143; doi 10.5488/CMP.10.2.143.

15. Bryk T., Holovko M., J. Mol. Liq., 2009, 147, 13; doi 10.1016/j.molliq.2008.10.014.

16. Virtanen J.J., Makowski L., Sosnick T.R. Freed K.F., Biophys. J., 2010, 99, 1; doi 10.1016/j.bpj.2010.06.027

17. Berendsen H.J.C., Grigera J.R., Straatsma T.P., J. Phys. Chem., 1987, 91, 6269; doi 10.1021/j100308a038

18. Aqvist J., J. Phys. Chem., 1990, 94, 8021; doi 10.1021/j100384a009

19. Palinkas G., Riede O., Heinzinger K., Z. Naturforsch. A, 1977, 32, 1197.

20. Jorgensen W.L., Maxwell D.S., Tirado-Rives J., J. Am. Chem. Soc., 1996, 118, 11225; doi 10.1021/ja9621760

21. Becke A.D., J. Chem. Phys., 1993, 98, 1372; doi 10.1063/1.464304.

22. http://www.ccp5.ac.uk/DL_POLY_CLASSIC/

23. Melchionna S., Ciccotti G., Holian B.L., Molec. Phys., 1993, 78, 533; doi 10.1080/00268979300100371

24. Druchok M., Hribar-Lee B., Krienke H., Vlachy V., Chem. Phys. Lett., 2008, 450, 281; doi 10.1016/j.cplett.2007.11.024

25. Druchok M., Vlachy V., Dill K.A., J. Phys. Chem. B, 2009, 113, 14270; doi 10.1021/jp906727h

26. Lund M., Jungwirth P., Woodward C.E., Phys. Rev. Lett., 2008, 100, 258105; doi 10.1103/PhysRevLett.100.258105

27. Rembaum A., Noguchi H., Macromolecules, 1972, 5, 261; doi 10.1021/ma60027a007

28. Williams S.R., Long T.E., Prog. Polym. Sci., 2009, 34, 762; doi 10.1016/j.progpolymsci.2009.04.004

29. Layman J.M., Borgerding E.M., Williams S.R., Heath W.H., Long T.E., Macromolecules, 2008, 41, 4635; doi 10.1021/ma800549j

30. Zelikin A.N., Akritskaya N.I., Izumrudov V.A., Macromol. Chem. Phys., 2001, 202, 3018; doi 10.1002/1521-3935(20011001)202:15<3018::AID-MACP3018>3.0.CO;2-7

31. Otrin-Debevc K., Pohar C., Vlachy V., J. Solution Chem., 1996, 25, 787; doi 10.1007/BF00973785

32. Krienke H., Vlachy V., Ahn-Erchan G., Bako I., J. Phys. Chem. B, 2009, 113, 4360; doi 10.1021/jp8079588 


\title{
Взаємодія модельних іонів алкілтриметиламонію з іонами лужногалоїдних солей: моделювання методом молекулярної динаміки із явно врахованими молекулами води
}

\author{
М. Дручок ${ }^{1}$, Ч. Подліпнік ${ }^{2}$, В. Влахи는
}

${ }^{1}$ Інститут фізики конденсованих систем НАН України, вул. І. Свєнціцького 1, 79011 Львів, Україна

2 Факультет хімії та хімічної технології, Університет Любляни, вул. Ашкерчева 5, 1000 Любляна, Словенія

У роботі з допомогою методу молекулярної динаміки проведено моделювання низькоконцентрованого розчину іонів алкілтриметиламонію (з кількістю метиленових груп у ланцюгу $3,5,8,10,12$ ) у суміші із солями $\mathrm{NaF}, \mathrm{NaCl}, \mathrm{NaBr}$ або NaI при температурі 298 К. Для опису води використано модель SPC/E. Результати представлено у формі низки радіальних функцій розподілу між атомами азоту чи вуглецю (із груп $\mathrm{CH}_{2}$ ) алкілтриметиламонію та контріонами розчину. Для детальнішого висвітлення результатів також наведено біжучі координаційні числа між атомами вуглецю та контріонами. Виявлено, що контріони $\mathrm{I}^{-}$демонструють найвищу, а $\mathrm{F}^{-}$найнижчу здатність асоціювати із іонами алкілтриметиламонію. Огляд результатів проведено у світлі наявних експериментальних та теоретичних даних для цих чи подібних систем.

Ключові слова: сурфактанти, солі алкілтриметиламонію, лужногалоїдні солі, зв'язування іонів, молекулярна динаміка 